\title{
The Impact of Corporate Strategy on the Capital Structure of Pakistani Companies (Diversification and Capital Structure)
}

\author{
Muhammad Uzair ali ${ }^{1}$, Gong zhimin ${ }^{1}$, Muhammad Rizwanullah², Xiong Wu ${ }^{1} \&$ Itbar khan $^{1}$ \\ ${ }^{1}$ Business School of Xiangtan University, Xiangtan, Hunan, China \\ ${ }^{2}$ School of Public Administration Xiangtan university, Xiangtan, Hunan, China \\ Correspondence: Zhimin Gong, Business School \& Socialist Economy Theory Research Centre, Xiangtan \\ University, Xiangtan, Hunan 411105, China. Tel: 86-0582-98818. E-mail: gzm@xtu.edu.cn
}

Received: April 20, 2020 Accepted: May 15, 2020 Online Published: May 19, 2020

\begin{abstract}
Research into the capital structure of firms has been the subject of extensive empirical investigation. This study seeks to extend the debate by examining the endogenous influence of corporate strategy on financing decisions made by firms. Diversification is one of the corporate strategies that allow a company to enter business lines that are same or different from current operations as well as operate in several economic markets. Financial choices need to be evaluated because of their close interaction with management choices. Optimal capital structure plays a key role in achieving the overriding goal of financial management. The study sought to discover the impact of corporate diversification strategies on financial choices because study main focus is diversification strategy (A type of corporate strategy). For purposes of comparison, the current study used four of the nine Rumelt categories which correspond to Wrigley's original four, which were single product strategy, dominant strategy, related firm strategy and unrelated firm strategy. Panel data model was constructed and using a sample of 120 companies listed on the Pakistan Stock Exchange and data was obtained for companies with seven years' quarterly data annually from 2010 to 2017. Using empirical tests, we found no relationship between diversification and leverage. Our analysis suggests that Diversifications strategy impact on capital structure indicate that this focus of enquiry has considerable potential for further resolution of the capital structure puzzle.
\end{abstract}

Keywords: Diversification strategy, Capital structure, Single product strategy, Dominant strategy, Related firm strategy, Unrelated firm strategy

\section{Introduction}

\subsection{Background of the Study}

In corporate finance discipline capital structure has been the center of focus in different researches. Capital structure theoretical dialogues initiated from suggestions of Modigliani and Miller (1958). They stated that cost capital and value of the firms is independent to capital structure (Bhaird, 2010). In 1958 the suggestion on capital structure was based on unrealistic assumption while in another research by Modigliani and Miller (1963) the effect of taxes was incorporated into the model. This resulted in the creation of the tradeoff theory of capital structure. According to trade off theory tax related benefit is being offset by the financial distress cost (Bhaird, 2010). Corporate strategy basic concern and apprehension is how a firm and an organization builds and create value across its business units. Corporate strategy enables a corporation to create and increase its competitive advantage and recommends a corporation how it can create value across business units (Collis, 2013). Corporate strategy compels a corporation to invest in values resources, craft business portfolio, structural design of the corporation and various corporation 's function in order to share activities or transfer skill across business activities (Collis, 2013).

Corporate strategy varies from company to company, which has an effect on firm's behavior in choosing between debt and equity financing. For growing companies, the capital structure decision becomes center of concern. Capital structure and diversification are two different concepts of management world that have different impact on various other aspect of financial management and business world. Interaction between capital structure and diversification is under focus and interesting for different studies because of their strong strategic connection and implication concerning corporate governance. Because of their close associations with management choices and capital structure different financial choices are evaluated (Cariola \& Rocca, 2007).

According to Monteforto \& Staglino (2011) in recent year's different studies has been done on impact and 
relationship of diversification on capital structure. Different researchers have investigated the interaction between capital structure and corporate diversification strategy. A number of studies suggest that a diversification firm needs large amount of leverage in order to enhance and increase value of the firm. Corporate diversification is critical and key aspect of corporate strategy for the growth and expansion of firms (Davidson \& Suchard, 2002).

To accomplish the prevailing goals of financial management the optimal mix equity and debt of capital structure always play a key role. An organization has to set a target capital structure in order to achieve these goals and objectives. Vries (2010) suggested that there are diverse factors affect capital structure decision process and choices so firms should be aware themselves of such factors. In this study, we are interested to dig out role of diversification in different financial choices. This will help in clarifying the behavior of companies in translating various diversification strategies into diverse corporate financial behaviors.

\subsection{Significance of Research}

Current Research would be valuable to many business groups and people. Impact of corporate strategy on capital structure is an independent analysis and firm's mangers could take benefit from current study. To up hold their desired capital structure, it will help management in implementing and formulating a relevant corporate strategy.

Current study should be added to pool of literature on capital structure and corporate strategy so that business researcher can seek guidance from. Current study can be a base for other future studies pursue by different scholars which are interested in study of corporate strategy and capital structure because it will provide factual information and data for further help and support and understanding of the methodology.

\subsection{Research Objective}

Corporate Diversification strategy, a type of corporate strategy which is the center of focus of the study and its relation is tested with leverage. Study objective is to find impact of corporate diversification strategy on capital structure by selecting different firm listed at Karachi stock exchange.

\subsection{Scope of the Study}

Scope of this research limited to many sectors for example textile, fibers, food, medicine, Automobiles, wool, cosmetics, oil \& gas, which are Pakistani companies listed at Karachi stock exchange except banking and insurance sector.

The rest of the study has been divided in such manner that the second section is the literature review, includes literature on the relationship between corporate strategy and capital structure. Section three contains the Methodology and econometrics analysis results. The last section is the summary and conclusion.

\section{Literature Review}

\subsection{Introduction}

Various scholars and researcher work has been discussed in this chapter. The arguments are about capital structure $\&$ corporate strategy and to conduct the proposed study diversification strategy (type of corporate level strategy) is the main focus and center of attention of the study. Various empirical and theoretical reviews are done on corporate strategy, diversification strategy and capital structure.

\subsection{Capital Structure}

Capital structure creation result from the mix of debt and equity instruments, these instruments are used to finance different firm assets and its operation (Ajay, 2012). Capital structure composition are common stock, preferred stock and debt, capital structure vary from firm to firm (Madhumathi, 2012). Huge challenges for a manager is the selection of optimal capital structure which is mix of securities that results in maximization of firm value through minimizing the financing cost of firm operation (Benjeman, 2012).

Optimal capital structure is a firm' capital structure with low weighted average cost of capital results in increase in value of company stock on which share prices maximizes (Chen, 2004). Capital structure generates opportunity along with apply limitation on the firm, so it has significant implication for the operation of the firm (Chen \& low, 2004). Management of the firm should set an optimal capital structure that leads to increase in value of the firm because a false capital structure set by management can throw a firm in financial distress and suffer bankruptcy eventually (Poddar, 2014). Debt financing is fruitful for firm because it has low cost of capital and also income is shielded from taxes but it also creates risk for example when a firm unable to pay periodic interest and loan payment will result in financial distress and bankruptcy situation (Koehhar, 1996).

When the capital structure cost of equity fall consequently then is good and the main advantage of debt is investor face less risk then equity and also the interest paid on loan has tax advantage (Markopoulos, 2008). On the opposite 
side it has disadvantages, it enhances the variance of earning "which stimulate investor to ask for greater returns" and when a firm often require debt then the increase cost of financial distress considerably (Papadopoulos, 2008).

In equity financing converse to debt financing the firm is not directly obligate to repay the fund and equity investor become owner of the firm, they are able to exercise some firm' management control (Enow, 2010). However, to administer some type of stock's sale for example IPO can be very complex process and expensive also because of management regulations, need of help of expensive \& costly attorneys and accountants (Benjamin, 2012).

Modagalai and miller forward a theory, capital structure doesn't have affect and influence on firm value but having influence on underlying assets. Rajan \& Zingalas in 1995 cleared that it depends on the objective of analysis to select a choice for a relevant measurement, in their study it was concluded that ratio of debt over capital (Defined as total debt plus total equity) better present the effects of past financing decision. Rocca in 2009 shows "leverage as ratio of total financial debt to total financial debt plus equity". In 2009, Rjaendar measured leverage as ratio of total debt to total equity, a ratio equal to 1 imply the presence of even debt \& equity, ratio less than 1 show low level of leverage and when ratio greater than 1 mean having greater leverage.

\subsubsection{Theories of Capital Structure}

\subsubsection{Trade off Theory}

Trade off theory suggests, in Firm's capital structure the debt is valuable and beneficial to equity financing. Firm is being rewarded to a point at which the benefit of tax deductibility of firm offset potential bankruptcy costs and moreover increases the firms to a highest point at lowest weighted average cost of capital (Ghazouani, 2013). M\&M theory leads to appearance of trade off theory. They argued that a firm shareholder should obtained benefit from debt in capital structure because debts have tax advantage over equity (Ghazouani, 2013).

Static and dynamic are two types of trade off theory; Static theory suggests that there is advantage and disadvantage of using more debt in capital structure than equity. So firm should create an optimal capital structure that margin of debt and equity is balanced (Scott, 1977). The initial focus of static trade off theory was on tradeoff between bankruptcy and tax advantage of debt (Meckling, 1976).

"In dynamic trade off theory Fischer, Heinkel and Zecher (1989) find that even in trade off setting with a fixed cost using equity, firms must stray from their target capital structure adjusting leverage only when it goes beyond extreme bounds". This happens when company makes profit and pay offs its debt and cause in fall of leverage automatically (Zecher, 1989).

\subsubsection{Pecking Order Theory}

When firms go for financing their business activities they will have a particular preference order for acquiring capital for their business, going for retain earning to debt, prefer short term debt over long term debt and Leverage (Myer \&Majlub, 1984). Information asymmetric can be resolved when a firm support investment opportunity through retain earning and not through issuance of new security. "When asymmetric information outsider and insider increases then issuance of new securities become very expensive" Firm should acquire or issue only debt financing when the asymmetry information is at peak to avoid selling underpriced securities (Frank, 2005). New stock issuing event which is capital structure decreasing event will result in stock prices decline of the firm. The conclusion is that pecking order theory made on the base line that manger in a firm facing undervaluation of stock should refrain itself from issuing securities (Furrer, 2011). "A company issues the safest security first if external finance is requiring; issues debt, then possibly hybrid securities such as convertible bonds, equity only as a last resort" (Jong, 2007).

\subsubsection{Signaling Theory}

Akerlop and Andrew use first the concept signaling in context of job and product market and Spence in (1973) developed it into signal equilibrium theory. Signaling theory is all about how an efficient and good firm is distinguishing from bad firm by sending signals about its quality to market. If the bad firm don't send false signal and don't mimic the good firm, then the signal will be credible for bad firm. It is not worthwhile to mimic good firm if the cost of signals is higher for bad firm than good firm and so the signals will be credible. To separate good firm from bad firm's debt can be used as costly signal suggested by Ross (1977).

"Firm signal are crucial for obtaining finance, under asymmetric information between investor and manager", Investor doesn't know the true distribution of firm return but manger does know. Good quality firm use more debt and low quality firm use less debt and it represent an optimistic future through signaling of using higher debt by manger (Ross, 1977). "When production signals consume resources then it is costly or signal is associated with a loss in welfare by which a firm shows deviation to allocate and distribute claims in capital market". The signals 
are multivariate for financial instruments. New entrant firm potential competition can be differentiating though debt signals (Poivten, 1989). Signal to market by low cost entrant is issuing debt while high cost entrant issue equity (Ravive, 1985).

\subsection{What is Corporate Strategy?}

Corporate level strategy is conceptualization describing the various pattern of decision through objective and goals of the corporation. There by, producing the main or principle policy to achieve and realizes those goals and objectives. Corporate level strategy also defines the types and forms business that a company wants to pursue (Andrew, 1971). Corporate level strategy is all about an overall plan for diversified company or firm. While business level strategy is all about how to hold build a sustainable competitive advantage in identical and discrete market or business. Corporate strategy of a company acts both as catalyst and constrain of the business unit strategy because if business level strategy unable to match corporate level strategy then it is impossible to build synergy (Porter, 1987).

Corporate strategy is all about selection and development of market in which company or firm having intent to compete and grab market share. The crucial endeavor of corporate strategy is what type of industry or market the sought to compete. Corporate strategy has two basic dimensions how a firm can be diversifying and how a firm can be vertically integrated (Furrer, 2011). The three building blocks of corporate strategy which we can say from which corporate strategy is motivated. Building blocks of corporate strategy are shared resources, transparent competencies and creation of specific assets. Shared resources block is taking something that firms already have it and use acquired resources in new industry (Furrer, 2011). An organization has competencies in which a firm uses to good in it. Transparent competency is acquiring something in which a firm has been excellent and uses it new in the new industry or market. Specific asset are those organizational assets having lower value on second use (Scott, 2003).

\subsubsection{Corporate level Strategies}

\subsubsection{Concentration Strategy}

Corporate level strategy where a firm concentrate on its primary level of business thrived for to gain increasing in its level of operation in primary business. Benefit of concentration strategy is to remain in its core business (Triant, 2006). Through concentration strategy, a company cans achieve growth through concentrating all its effort on improvements of business operations (Traints, 2006). Concentration strategy adopted by the firm to realize growth, entail that according to firm's customer needs and alternative technologies firm apportion its resources into its single or more business- in such that result in expansion or growth (Sharon, 2000). In practical term, concentration strategies is all about using a verified technology and make investment of resources in a product line for an identified market and whenever there is opportunity for growth or expansion concentration strategy must employed (Owsal, 2002). The industry in which the business uses to operate should have the opportunity and potential for growth and for concentration. It should be attractive from the firm internally view because the firm must have the power to sustain the growth and expansion and for expansion there must need of additional resources for investment (Flouris, 2003).

\subsubsection{Integration}

Integration is a growth strategy (corporate level strategy) and when a firm adopts integration strategy it results in increase and widens the business scope (Scott Gallagher, 2003). Integration corporate strategy results in doing some different from what a company is previously doing. Transaction based economics best explains which integration strategy is to choose, "according to transaction based economics, 'a buy or make' decision is made when a firm wants to negotiate with its suppliers and buyer (Gallagher, 2003). The cost making product is evaluated against cost of procuring it from suppliers, if the cost of manufacturing is less than cost of procurement then company will ought to produce its product and will perform integration because they will move up the value chain (Shroon, 2006). Likewise, it is better for a firm to move down in the value chain if the cost of selling the finished product if the price paid to seller is high in order to sell the finished product than cost of selling the product by itself, in both cases the firm is following corporate integration strategy (vertical Integration) (Kazmi, 2003 ). Vertical integration adding something thing new to business to cover its own needs and keep the original business at the same level but the business portfolio increases (Scott, 2003). Horizontal integration strategy is "when a firm takes up the same type of product at the same level of production and marketing process" (Obara, 2008). To expand geographically though merger or buying competitor business is horizontal integration and it provide a large market base for merger firm (Obara, 2008). 


\subsubsection{Diversification Strategy}

For research finding, diversification strategy is main focus and concern of the study. In the course of this corporate level strategy single or jointly substantial change is made in business definition or portfolio, diversification is entrance of a firm into new lines of activities which bring out changes in its systems, administrative structure and other process of management through process of acquisition or business development (Ramanujam \& Varadarajan, 1989). The change may be of different perspective for example change in term of customer group, customer function, or alternative technologies of one or more of a firm's business. There are two basic diversification strategies (Nayyar, 1990). When a firm takes up business activates that is related to current or original business activates or definition in different terms and perceptive then it is Concentric Diversification. Conversely when a firm adopts a corporate strategy by adding a product line or business activates bring different and unrelated to original definition of the business, it leads to Conglomerate Diversification (Kazmi, 2003).

\subsubsection{Theories related to Corporate Strategy}

\subsubsection{Resources Based View}

According to resource based view, for competitive advantage, performance and growth the company resources and firm's assets are the fundamental determinants. A firm controls a bundle of resources and the model assumes that firm or company in strategic group may heterogeneous to the resources they control (Ongeri, 2014). It also assumes that heterogeneity of resources will continue to exist overtime because for implementing Firm's strategy the resources across the firm are not perfectly mobilize. Thus it has been cleared that unique resources and capabilities of the firm defines and describes the essence of strategy and these resources may be acquired through debt or equity financing, so it also characterizes the mix of capital structure (Lewellen, 1971).

\subsubsection{Transaction Based Economics}

Transaction based economics primary focus on "vertical integration or buy or make decision Questions". Transaction based economics plays a vital role in distributing of the activities of the firms over industries determining (Ongeri, 2014). Transaction based economics focuses on firm choices to involve in diversification in new industry or outsource any valuable asset of the firm in that industry. It doesn't make predication that in which specific industry the firm should diversify but it can with other approaches for example Resource based view, specify that where and when a particular asset will is useful (Lishenga, 2012). Transaction cost economics approach is helpful in firm boundary study, decision of vertical integration. Transaction cost economics also can be used as rational in conducting an acquisition (Barney, 1991). In Transaction cost economics there is existence of a close parallel between corporate finance and vertical integration. Firm core competency and focus in longterm decision to buy or make is determined by the boundary decision faced by firm. To finance investment through equity or debt is a decision in corporate finance is for the firm another make or buys decision.

\subsubsection{Co-insurance Effect}

The coinsurance effect combat with operating risk reduction because when a firm or company involve in different business and cash flow inverse business results in different cash flow and result to imperfect relation between these cash flow causing operating risk (Lishenga, 2012). Co-insurance effect is most appropriate for those firm involving and developing unrelated corporate strategy because unrelated business results in "lack of relation" between cash flows of the business is greater, "these firm should use more debt (Lewllen, 1971". Co-insurance effect is actually a corporate level debt theory aims that a risk faced by a firm can be reduce when a firm diversify its operation (Klein \& Lien, 2009). The influence of coinsurance effect on debt capacity is positive, due to firm revenue volatility reduction and profit. Moreover, firm's asset's future rent stream could be accurately estimated by debt holder results in improvement of firm borrowing ability and debt capacity.

\subsubsection{Role of Corporate Strategy}

Andrew and Mintzberg and water (1982) presented an approach, corporate strategy are realized pattern in the flow or stream corporate actions and decisions. Corporate strategy reflected in every firm objective and policy. Corporate strategy crystallizes the population of organization that will emerge in the process and it also improves the instruction that an organization have from their stake holder (Andrew \& Mintzberg, 1982).

Corporation being involved in portfolio of multiple businesses activities, identified as those plans and actions which have influence on their different portfolio, this concerns the extent to which companies diversified from its core business. Mintzburg (1988) identify generic strategy that leads to creation of these corporate strategies that are differentiated on the basis of distance from core business and firm activities original focus. According to empirical evidence on the failure of merger and acquisition, to generate value of synergy to its stock holder and frequently spread of risk was taken as rationale (utility) for merger activity, all this leads to reinforcement of this 
view of corporate strategy. According to Porter (1985) the result and track record of corporate strategy is dreadful because most of the companies shattered rather than creating shareholder value. Porter argument was supported by data, in unrelated firms with average of divestment rate of $74 \%$ occurred while over $50 \%$ of in related acquisition. Strategy may pop out or emerge in response to changing circumstance of the environment, so strategy might not be a plan activity. So a clear and transparent methodology will be necessary for empirical research and categorization of corporate strategy will be necessary for useful study of corporate and capital structure relationship. Wrigley (1970) and Rumelt (1971) used sale turnover analysis forms the basis of strategy taxonomy. Barton and Gardon on their 1998 study used the modified version of Rumelt strategy taxonomy. For the aim of comparison, the study applies four of the Rumlet categories.

The main motive of the research study is to uncover the impact of diversification on capital structure, so major idea of categorization is a taxonomy that figure out the diversification strategy of the company which is based on two ratios, one of the two ratios is specialization ratio, defines as the proportion of the sale of the company accounted for each activity. Second is relatedness approach, the proportional relatedness of the company having common skill or resources dependence and utilization (Montogamry, 1982). "Specialization and relatedness approach is measurement of diversification at cooperate level strategic measure". That is very profitable and reliable measure of strategy which is consistent with studies of business unit level. But of course there is some methodological problem with approaches "relatedness approach can may be in term of market or product, however, it may be also in term of commonality of research and marketing and as a Galbraith (1993) suggest that the center of gravity of the business". "Across various aspects of value chain relatedness has been identified by porter and Porter emphasize how fit, differs from markedly fit and diversification, when focus on performance in the Ansoff (1965) mode, which was directed mainly directed at growth".

The relationship between diversification and performance was examined and market structure was the key factor, all this was confirming by Change and Thomas (1989). The impact of corporate strategy variable has been effectively masked by Industry structure, this key influence was confirmed by Water and Mantgomer (1998). In finding and determining the diversification performance, the route or pathway through which a company achieves diversification also can be identified as significant factor. Internal generated growth which achieved through acquisition, demonstrate the superiority of growth (Simon, 1998).

Advancement in financial innovation for example junk bond has enhanced the credibility and the power of takeover threats which could make the stockholder and managerial coverage strategies coverage. At the same time due to concern for individual and single security associate with inadequate $\&$ insufficient cash flow and risk of bankruptcy will result in manger may threaten by highly debt/equity ratios (Berley\& Means, 1932), "all the equity firm show high level of managerial ownership control" (Agarwal, 1990).

\subsection{Relationship between Capital Structure and Corporate Level Strategy (Diversification Strategy)}

Modigliani and miller (1958) suggest that in case perfect or efficient market financing decisions are "irrelevant" for firm strategy. However, Mayer and Majluf (1984) cleared that because of several implications "in real world such choices may differently affect value of the firm". Strategist argued, there is a strategic importance in every financial decision, especially in affecting corporate governance (Bromileym, 1990). Tradition finance paradigm has been complemented by corporate strategy and also enriching the comprehending of capital structure decision of the firm (Barton \&Gardon, 1987).

Diversification corporate level strategy is the center of attention of the study; it is necessary to explain the relation of diversification with debt and equity financing (capital structure). Product Diversification and international diversification can be explained with help of coinsurance effect, suggesting that risk can be minimized when we diversify activates (Lewellen, 1971). Firm debt capacity can be boost through reducing risk leads to a positive relationship between leverage and degree of diversification (Apostu, 2010). Aggregate businesses activities have imperfectly related cash flow stream decrease the variability of earning for a combined business, expected loss become more predictable and reduction in variability of earning can $b$ achieved when insurance pool magnitude increased through product and geographical diversification (lewllen, 1971). Extending this theoretically, coinsurance effect results in enhancement of market value of Diversify firm debt and associatively decline in value of its equity (Higgins \& Schatt 1975).

Diversification has impact on capital structure; Banerjee (2011) argued that value to the firm has been added by debt capacity so through overall debt capacity diversification enhance value of the firm. To increase shareholder wealth diversified firm may have greater debt capacity than firm don't involve in diversification (Sing et al, 2002). A firm operating in multiple markets help the firm a business to diversify risk and smooth earning volatility, make the firm to grab the benefit of issuing more debt (O’ Brien, Tork \& Andrew 2013) 
A considerable amount of literature has shown that there is negative relationship between corporate leverage and international diversification. Multinational diversifications try to carry low debt than local business. Several others study has stated that product diversification is possibly unrelated to debt usage and them also showed that it may be unrelated in nonlinear manner or negatively related to debt usage (Singh et al, 2002; Michale \& Mhaked, 1986).

\subsection{Diversification Types (A Bases for Examine Data)}

For the purpose of comparison current study employed four of the nine Remult categories. Ranging from no diversification to extensive diversification Remult in 1974 define and present four levels of corporate diversification strategy, single product, Dominant business, related business and unrelated business. In single product business firm focuses on its original business definition and don't venture or invest in new business and remain in its original business (Bruche, 2000). In single product firm receive revenue by $95 \%$ through a single product line. Second is dominant business, firm involved in some diversification from its original business but original business remains dominant and continue to sustain and exist. In dominant firm $70 \%$ to $95 \%$ of revenue come from original business (Mayer, 2002). Third is related business, from a single business less than $70 \%$ of revenue is received but through addition of more activities firm and those activates are alike and tangibly related to its original activities. Firm businesses are characterized by similar in product, market and technology so these businesses are related to each other's. Last is unrelated business, (conglomerate) also called multi business and unrelated portfolio. In this type of diversification the firm adds unrelated activates to original business definition and diversify into those activates which unrelated to core skills and strength (Furrer, 2010).

A firm involved in related diversification, try to collect more specific assets while companies busy in unrelated diversification add less specific assets. Undiversified firms as well as related diversified firm have lower debt level mentioned by Barton and Gordon (1988) and firm pursuing unrelated diversification has level of higher debt. Kocher and Hitt in 1998 also found that related diversification is coupled with equity finance while related diversification is associated with debt financing. Highly diversified firms have different Leverage ratios, and characteristics of growth, risk and cash flow from less diversified firms. While Between geographical and firm leverage a negative relation was find out by Singh \& Davidson (2003) and a positive relationship was defined by low and Chen (2004). The strongest determinants of firm leverage are asset type, firm diversification and availability of tax shields (Jahera \& Lloyed, 1996).

\subsection{Empirical Literature Review}

A research on capital structure and corporate diversification strategies was conducted by Singh et al (2002) relation investigation was main objective of the study and its impact on corporate leverage. New York stock exchange (NYSE), American express and Nasdaq listed U.S firms having annual sale greater than US \$100 million while excluding those firms that offers regulated utilities and financial services. Study data was collected for period of 1994-96 and secondary data was analyzed. Parametric test statistics and multivariate regression analysis was used for data analysis. The study finding was for controlling variable like geographic diversification, assets turnover, firm sizes as well as other variable, "Product diversification is at best unrelated to debt usage and may either negatively related to debt usage or in some instance related in non-linear manner". However, this will increase negative influence of international diversification on leverage "as they establish MNC that product diversified has lower leverage ratio than domestic firm".

Change et al (2008) conduct a study on capital structure determinants. 13887 firm-year observations was sample size and descriptive statistics was used to analyze it. Capital structure being measured through "ratio of short term debt to long term debt and convertible debt to market value of equity". As a result on capital structure the most influential determinant will be the growth when its measured "as market to equity ratio (MBE) or market to total asset ratio book asset ratio (MBA) out of the seven factor of the research: growth, profitability, non-tax shields, uniqueness, collateral value, volatility and industry". "Growth has negative impact on leverage on measure with MBA ratio while it has positive effect on leverage when measured with MBE ratio". They made a conclusion that the study seven factors have significant effect on capital structure under the simultaneous cause effect frame work.

Nunkar \& Boateng (2010) conduct a research and revealed that tangibility and profitability has major and positive impact on leverage in Canadian firm context. Size and growth opportunities have negative impact on leverage ratio in context of Canadian firm. The size variable coefficient had been negative and significant. Capital structure is positively related to geographic diversification and product diversification individually "but the interactive variable between product and geographic diversification had a negative and significant coefficient". The study investigate "the interactive effect of product diversification and geographical diversification for the penal of medium and large Italians firm the interactive effect of product diversification and Geographic diversification on capital structure on capital structure". "They suggested that volatility of earning and cost of financial distress can 
be reduces through combing business with cash that are not perfectly related. The result is increases stock holder value and reduces cost of capital and an overall impact on debt level".

A study that was by Nayanmba, Nyangwesa \& Omari (2013) on factor that will determine the capital structure of microenterprise were targeted by study. Study identifies 80 microenterprises through random simple design. Case study made clear that as compared to other some capital structure determinants are more significant. Access to capital market, business profit profitability, market size and the attitude of lenders towards firm are the greatest determinants being identified.

A study done Guo (2011) identify that diversification has two possible reasons. To reduce under investment problem leads to firm diversification seeking. Firm or organization having lower level of expenditure of capital will go for increase in diversification level. External financing for a firm is costly and diversification makes a firm to have greater internal capital which they make to avoid external financing and in result firm avoid underinvestment's problem. Second reason is it creates more stock holder value because to grab growth opportunity firm diversify to support future growth. Moreover, adding to the above-mentioned considerations, "digital technologies and innovation advancements" are uninterruptedly changing companies' strategic choice (Dobusch \& Kapeller, 2017). Furthermore, Integration \& internationalization are negatively related with capital structure whereas diversification has been positively related with capital structure.( Author links open overlay panel (Francesco, Giorgio Raffaele, 2019).

\section{Methodology}

\subsection{Introduction}

Study Research design and methodology are presented in this chapter for the purpose of performing and executing study. Research design, population and sample, data collection and data analysis have been discussed and explained in this chapter.

\subsection{Research Design}

For the sake of accomplishing research objective Research design section consider and focus on Research techniques used and adopted for current study. The method used to perform the study is actually research design said by Megend \& Mugenda (2003). The study data is Panel data while panel data refers to sets of data containing multiple of observations on each and every sampling unit. Panel data generate through pooling time-series observations transversely an array of cross-sectional units. Panel data is also known for longitudinal data or crosssectional time series data. Panel data design is considering appropriate because current data is observational and being collected from annual reports of different companies listed at Karachi stock exchange.

\subsection{Population \& Sample}

Study population is drawn from companies listed at Karachi stock exchange. Study includes one hundred and twenty (120) companies with seven years' quarterly data annually from 2010 to 2017. Companies belong to different sectors; cement, oil, Pharmaceuticals, cosmetics, food, fiber and automobiles, shoes, ceramics \& paints. The reason for excluding banks and insurance company is the financial statement (Balance Sheet) of a company concern and that of a banking concern have been organized differently because the act which rules the two are not same.

\subsection{Data Collection}

To classify the firms into diversified and specialized categories, there have been different methods proposed by different past literature. But lack SIC (Standard Industrial Classification) coding in Pakistan; the study's firms were divided as specialized and diversified on the basis of their product portfolio. It depends whether a company produces single product or multiple products. Whether a company use to sell only in domestic markets or domestics as well as export market (Akhtar \& Qurashi, 2011).

Study companies are from various sectors which are food, chemicals, automobiles, Fibers, cosmetics, cement and oil \& gas are being divided into four categories on the basis of their offering and product portfolio which are related diversification, unrelated diversification, dominant diversification and single product firms. Related data is selected from various sources including online publication of different firms and Karachi stock exchange for companies with seven years' quarterly data annually from 2010 to 2017. A total number of one hundred and twenty (120) companies make up our sample size. All the 120 companies are divided into four different groups based on their diversification strategies. Each group has equal 30 companies from different sectors. Study major focus is diversification and on basis of diversification, Pakistani firms are classified into four categories on the basis of their product portfolio and market. 


\subsection{Data Analysis}

To explore the relationship between capital structure and diversification, Panel data analysis technique is employed for controlling some variables because we are staring at the effect of one variable and all other Independent variables are held constant. Panel data analysis is used for controlling the heterogeneity of individual. While not controlling of individual heterogeneity in case of time series and cross section study will have the risk of getting the biased result. The advantage of using the panel data analysis is that it gives more informative data, gives us more variability, having less co-linearity within variables, more efficiency and more degree of freedom.

The included Control variables are size, sales growth, and capital intensity and profitability while Leverage is taken as dependent variable of the study. To get the answers for research questions the data is ordered and summarized. To link the relationship between Leverage and corporate diversification Random effect model is employed. Motivation behind random effects model is that variation across units is implicit to be random and unrelated with the independent variables included in the model. In study Hausman test had used to make certain the model's statistical consistency. Data is entered into excel spread sheet for purpose of operation of data before entering it into Gretle.

\subsection{Model Specification}

In current study Panel data model is based on regression equation model which is used to analyze significance relationship between variables with significance level of $5 \%$ and $95 \%$ of confidence interval.

DEBEQait $=\beta i+\beta S T R A T G Y i t+\delta$ Controlsit $+\varepsilon i t+u i$

DEBEQ $\alpha$ it is dependent variables, $\beta \mathrm{i}$ is model constant, $\beta$ STRATGYit explanatory variable that represents the degree of diversification of company (i) in time period ( $t$ ), $\delta$ Controlsit represent the control variables of the model and $\varepsilon i$ is the regression error.

\subsubsection{Capital structure \& Diversification strategy}

Study use Leverage as a proxy for capital structure and will be use as dependent variable.

A series of hypothesis were developed by Barton and Gardon (1998) which will be again tested in this study.

H1: There is low positive relationship between single product strategies with debt level.

$\mathrm{H} 2$ : There is an average positive relation of dominant firm with Leverage

H3: There is low positive relation of Debt levels with related diversification.

H4: There is High positive relationship between unrelated firm strategies with Leverage level

Other factors that can determine the borrowing capacity of firms were also considered Borrowing capability of the corporations can also determine by the Other factor so they must be considered. The following factors and control variables used to represent those factors are considered:

\subsubsection{Profitability (PROB)}

Profitability can be defining as average rate of return on total assets and high profitability leads to negative relationship with debt ratio supported by Friend and Hasbrouck (1988). So the hypothesis is profitability of a company is negatively related to Leverage ratio.

\subsubsection{Size (SIZE)}

For the size of a firm or company the logarithm of total assets of the firms is used as proxy. The adopted hypothesis for the size of the firm is size is positively related to Leverage ratio. There is literature to support for this hypothesis, although Lang \& friend (1998) presented a statically insignificance or weak support.

\subsubsection{Sales Growth Rate (GROW)}

Lender use to lend fund on future expectations and management may permit preventive debt structure in return for leverage growth. This is the case manager doesn't own a significant equity, so they will increase Leverage to enhance the sale growth in excess of normal industry rate (Kester, 1986). So with Leverage firm's sale growth will be positively related.

\subsubsection{Capital Intensity (CAPINT)}

Capital intensity can be defined as total fixed assets divided by current assets. Industry being highly capital intensive having large entry barrier and high capital intensity is associated with low earning risk and having ease in raising debts. Friend and Lang find a positive relationship. Hypothesis is capital intensity have positive relationship with debt ratio. 


\section{Data Analysis}

\subsection{Data Analysis \& Result Discussion}

The research finding are detailed and explained in this chapter and presented through tables and especially in the regression model the study population targeted firms listed at Karachi stock exchange of which 120 firms were selected for studies. To answer the Research Question, Data has been divided into four data sets according to nature of the Diversification Strategy and data being analyzed to find and explore the impact diversification on capital structure of the firms listed at Karachi stock exchange.

Table 1.

\begin{tabular}{llll}
\hline & Strategy & Mean values & Observation \\
\hline 1 & Single firm & $\mathbf{0 . 6 8}$ & $\mathbf{3 0}$ \\
\hline 2 & Dominant firm & $\mathbf{0 . 5 3}$ & $\mathbf{3 0}$ \\
3 & Related firm & $\mathbf{0 . 4 2}$ & $\mathbf{3 0}$ \\
4 & Unrelated firm & $\mathbf{0 . 9 3}$ & $\mathbf{3 0}$ \\
Sample & All & $\mathbf{0 . 6 6 4}$ & $\mathbf{1 2 0}$ \\
\hline
\end{tabular}

Usually unrelated firms have high level of debt than other firms which use other diversification strategy and have high debt ratio of 0.93 . Single firm and dominant firm have debt ratio of 0.68 and.053 respectively. Firms with related diversification have lowest debt ratio.

Table 2. Random-effects (GLS) Model - related firms (Dependent Variable: Leverage), using 599 observations Included 120 cross-sectional using 150 observations

\begin{tabular}{lllll}
\hline & Coefficient & Std. Error & t-ratio & $p$-value \\
\hline Const & -0.381852 & 0.777781 & -0.4910 & 0.6236 \\
PROFITABILITY & $-2.66613 \mathrm{e}-05$ & 0.000163762 & -0.1628 & 0.8707 \\
GROWTH & $1.60669 \mathrm{e}-06$ & $8.50792 \mathrm{e}-06$ & 0.1888 & 0.8503 \\
INTENSITY & $-4.67999 \mathrm{e}-05$ & 0.00196938 & -0.0238 & 0.9810 \\
SZIE & 0.111661 & 0.0780773 & 1.4301 & 0.1532 \\
Strategy & -0.275189 & 0.214267 & -1.2843 & 0.1995 \\
Mean dependent var & 0.645563 & S.D. dependent var & 1.418142 \\
Sum squared resid & 1181.087 & S.E. of regression & 1.410093 \\
Log-likelihood & -1053.283 & Akaike criterion & 2118.567 \\
Schwarz criterion & 2144.938 & Hannan-Quinn & 2128.833 \\
\hline
\end{tabular}

According to above data given in table 2, regression shows statistically an insignificant relation of related firm diversification and leverage because, at $95 \%$ confidence level single firm strategy has high p-value. So in term corporate financing decision related strategy has no impact on mix capital structure.

Table 3. Random-effects (GLS) Model - Unrelated firms (Dependent Variable: Leverage), using 599 observations Included 120 cross-sectional using 150 observations

\begin{tabular}{lllll}
\hline & Coefficient & Std. Error & t-ratio & $p$-value \\
\hline Const & -0.436526 & 0.771344 & -0.5659 & 0.5717 \\
PROFITABILITY & $-2.07049 \mathrm{e}-05$ & 0.000163708 & -0.1265 & 0.8994 \\
GROWTH & $1.8927 \mathrm{e}-06$ & $8.49963 \mathrm{e}-06$ & 0.2227 & 0.8239 \\
INTENSITY & -0.000145699 & 0.00197013 & -0.0740 & 0.9411 \\
SZIE & 0.101387 & 0.0785381 & 1.2909 & 0.1972 \\
\hline
\end{tabular}




\begin{tabular}{|c|c|c|c|}
\hline STRATEGY & 0.347205 & 0.215152 & 0.1001 \\
\hline Mean dependent var & 0.645563 & S.D. dependent var & 1.418142 \\
\hline Sum squared resid & 1176.880 & S.E. of regression & 1.407580 \\
\hline Log-likelihood & -1052.215 & Akaike criterion & 2116.430 \\
\hline Schwarz criterion & 2142.801 & Hannan-Quinn & 2126.696 \\
\hline
\end{tabular}

Observing the data in the table 3, the Regression displays a non-significant relation between unrelated firm strategy and leverage, as measured by Random Effect Model. Unrelated strategy of a firm has no significant impact on capital structure decisions at 5\% significance level while at 10\% significance level unrelated firm strategy display relation and impact on firm financing choices.

Table 4. Random-effects (GLS) Model - Single product firms (Dependent Variable: Leverage), using 599 observations Included 120 cross-sectional using 150 observations

\begin{tabular}{lllll}
\hline & Coefficient & Std. Error & t-ratio & $p$-value \\
\hline Const & -0.518518 & 0.772843 & -0.6709 & 0.5025 \\
PROFITABILITY & $-2.55487 \mathrm{e}-05$ & 0.000163955 & -0.1558 & 0.8762 \\
GROWTH & $1.96326 \mathrm{e}-06$ & $8.50832 \mathrm{e}-06$ & 0.2307 & 0.8176 \\
INTENSITY & $-3.9134 \mathrm{e}-06$ & 0.00197066 & -0.0020 & 0.9984 \\
SZIE & 0.117397 & 0.0781099 & 1.5030 & 0.1334 \\
STRATEGY & 0.0459616 & 0.215093 & 0.2137 & 0.8309 \\
Mean dependent var & 0.645563 & & S.D. dependent var & 1.418142 \\
Sum squared resid & 1189.048 & & S.E. of regression & 1.414837 \\
Log-likelihood & -1055.295 & & Akaike criterion & 2122.591 \\
Schwarz criterion & 2148.962 & & Hannan-Quinn & 2132.858 \\
\hline
\end{tabular}

In above table 4, there has been statistically insignificant relationship between single product strategy and Leverage show through regression, as measured by Random effect (GLS) because p-value is much higher at $5 \%$ confidence level. Single product strategy has no relation with financing choices of the firms.

Table 5. Random-effects Model - Dominant firms (Dependent Variable: Leverage), using 599 observations Included 120 cross-sectional using 150 observations

\begin{tabular}{lllll}
\hline & Coefficient & Std. Error & t-ratio & p-value \\
\hline Const & -0.443213 & 0.783325 & -0.5658 & 0.5717 \\
PROFITABILITY & $-2.52737 \mathrm{e}-05$ & 0.000163842 & -0.1543 & 0.8775 \\
GROWTH & $2.05815 \mathrm{e}-06$ & $8.50795 \mathrm{e}-06$ & 0.2419 & 0.8089 \\
INTENSITY & $-2.46272 \mathrm{e}-05$ & 0.00197047 & -0.0125 & 0.9900 \\
SZIE & 0.113801 & 0.0784503 & 1.4506 & 0.1474 \\
STRATEGY & -0.113936 & 0.215961 & -0.5276 & 0.5980 \\
Mean dependent var & 0.645563 & & S.D. dependent var & 1.418142 \\
Sum squared resid & 1188.102 & & S.E. of regression & 1.414274 \\
Log-likelihood & -1055.057 & & Akaike criterion & 2122.114 \\
Schwarz criterion & 2148.485 & & Hannan-Quinn & 2132.380 \\
\hline
\end{tabular}

In accordance to data in table 5, regression results show statistically an insignificant relation between corporate dominant strategy and leverage at 5\% significance level. The results in above table deny the impact of dominant strategy on firm choices for acquiring finance. 
The regressions results demonstrate a statistically non-significant relation between diversification and the level of corporate indebtedness, as measure through Random effect. As a result, in term of finance of a corporation either to issue bonds, issue stocks or acquire loan from banks corporate diversifications appear to present no advantage. Although at 10\% significant level unrelated firm's strategy show some sort of relation with leverage.

The essence of the study result is that Firms listed at Karachi stock exchange following each of the four Diversification strategies; either they adopt Unrelated Diversification strategy, related Diversification strategy, Dominant Diversification strategy or Single product strategy, will have no relation of their strategy with their choice of financial decisions. Corporation which is switch to any of the four given strategies don't have any impact on its Capital Structure decision.

However, when the debt level of various firms was calculated, the results show that firms which follows unrelated diversification strategy have highest level of debt compared to other three strategies while firms following related diversification strategy firms.

\section{Conclusion}

\subsection{Conclusion and Limitations}

The basic aim of study was to determine and dig out the impact of Diversification strategies (Unrelated firm strategy, unrelated firm strategy, single product strategy, Dominant product strategy) on leverage (Debt to equity ratio) of the Pakistani companies listed at Karachi stock exchange. To that end, study evaluated the relationship between Leverage and Level of diversification. Study data was collected from Firms listed at Karachi stock exchange and based on their level and type of Diversification firms were divided into four equal groups, related diversification firms, unrelated diversification firms, dominant firms and single product firms. Study data consist of 120 firms and were divided into four categories while each category had 30 companies.

Using a panel data model by incorporating Random effect model, no verifications or evidences were found that whether there is any financial advantage of diversification in Pakistani firms listed at Karachi stock exchange in the studied sample. This result seems at first sight contradictory to the results of the past literature previously discussed. Thus we conclude that use of Diversification strategy such has been carried out in Pakistan, does not bring positive results in term of corporation financing ability. Thus manager that focuses on mounting potential Financing should consider alternatives to corporate diversifications.

As a suggestion for future studies and research, it would be appealing to analyze more deeply the cause of absence of relation between corporate diversification strategies and leverage. Future study should dig out the cause and the compelling force that have impact on firms' choices either to issue bonds, stocks or take a loan from a bank.

\subsection{Limitation of the Study}

Problems and challenges faced during pursuing study were personal limitation and lack of expertise. Data collected for the study was from annual reports of the different Pakistani listed firms. Integrity of study findings was completely depended on the statements in annual reports posted on firm's websites. Any sort of misrepresentation and material error can make the Research findings limited.

\section{Acknowledgment}

This work has been supported by the National Social Sciences Foundation of China project to reconstruct the dynamic mechanism of effective supply and effective demand linkage and matching through income distribution reform (project, No. 17BL012). The Chinese Government scholarship (CSC Council Beijing China), is also greatly acknowledged for providing Financial support. (CSC No.2017DFH016032).

\section{References}

Aggarwal, R. (1990). Capital Structure Differences among Large Asian Companies. ASEAN Economic Bulletin, 7(1), 39-53. https://doi.org/10.1355/AE7-1C

Anshen, M. (1966). Corporate Strategy. The Journal of Business, 39(3), 426-427. https://doi.org/10.1086/294878

Bauerschmidt, A. (1993). A Comment on Gilbert's 'The Twilight of Corporate Strategy. Strategic Management Journal, 14(5), 397-399. https://doi.org/10.1002/smj.4250140507

Bowen, F. (2007). Corporate Social Strategy: Competing Views from Two Theories of the Firm. Journal of Business Ethics, 75(1), 97-113. https://doi.org/10.1007/s10551-006-9240-0

Collins, W. S. (Spring, 1988). Cultural Influences on International Capital Structure. Journal of International Business Studies, 19(1), 87-10. https://doi.org/10.1057/palgrave.jibs.8490376 
Damanpour, R. C. (1991). Institutional Ownership, Capital Structure, and Firm Performance. Strategic Management Journal, 12(7), 479-491. https://doi.org/10.1002/smj.4250120702

Daskalakis, M. P. (2009). Are the Determinants of Capital Structure Country or Firm Specific? Small Business Economics, 33(3), 319-333. https://doi.org/10.1007/s11187-008-9103-4

Diamantopoulos, N. M. (1987). Uncertainty and Synergy: Towards a Formal Model of Corporate Strategy. Managerial and Decision Economics, 8(2), 121-130. https://doi.org/10.1002/mde.4090080206

Dobusch. L., \& Kapeller. J. (2017). Open strategy-making with crowds and communities: Comparing Wikimedia and Creative Common Long Range Planning, 51(4), 561-579. https://doi.org/10.1016/j.lrp.2017.08.005

Fox, S. B. (1993). Asset Specificity, Firm Heterogeneity and Capital Structure. Strategic Management Journal, 14(1), 3-16. https://doi.org/10.1002/smj.4250140103

Gordon, S. L. (1988). Corporate Strategy and Capital Structure. Strategic Management Journal, 9(6), 623-632. https://doi.org/10.1002/smj.4250090608

Harris, F. H. (1994). Asset Specificity, Capital Intensity and Capital Structure: An Empirical Test. Managerial and Decision Economics, 15(6), 563-576. https://doi.org/10.1002/mde.4090150604

Helfat, E. H. (2001). Does Corporate Strategy Matter? Strategic Management Journal, 22(1), 1-23. https://doi.org/10.1002/1097-0266(200101)22:1<1::AID-SMJ143>3.0.CO;2-T

Ireland, M. A. (1985). Corporate Distinctive Competence, Strategy, Industry and Performance. Strategic Management Journal, 6(3), 273-293. https://doi.org/10.1002/smj.4250060307

Julian Lowe, T. N. (1994). The Impact of Corporate Strategy on the Capital Structure of Australian Companies. Managerial and Decision Economics, 15(3), 245-257. https://doi.org/10.1002/mde.4090150306

Lucey, C. M. (October 2010). Determinants of capital structure in Irish SMEs. Small Business Economics, 35(3), 357-375. https://doi.org/10.1007/s11187-008-9162-6

Mohamad, M. H. (1995). Capital Structure in Large Malaysian Companies. MIR: Management International Review, 35, Euro-Asian Management and Business II- Issues in Foreign Subsidiary and National Management, 119-130. https://doi.org/10.1007/978-3-322-90985-5_9

Palmon, S. H. (1983). The Irrelevance of Capital Structure for the Impact of Inflation on Investment. The Journal of Finance, 38(3), 785-794. https://doi.org/10.1111/j.1540-6261.1983.tb02501.x

Senbet, J. E. (1990). International Capital Structure Equilibrium. The Journal of Finance, 45(5), 1495-1516. https://doi.org/10.1111/j.1540-6261.1990.tb03725.x

Sinha, S. (1993). Inter-Industry Variations in Capital Structure. Economic and Political Weekly, 28(35), M91-M94.

Sufi, J. D. (December 2010). Capital Structure and Debt Structure. The Review of Financial Studies, 23(12), 42424280. https://doi.org/10.1093/rfs/hhq095

Thomas, T. H. (1983). Microeconomic Foundations of Corporate Strategy. Managerial and Decision Economics, 4(3), Corporate Strategy, 127.

Tombak, R. S. (2002). Investment, Capital Structure, and Complementarities between Debt and New Equity. Management Science, 48(2), 257-272. https://doi.org/10.1287/mnsc.48.2.257.260

Verbeke, A. M. (1998). Corporate Strategy and International Environmental Policy. Journal of International Business Studies, 29(4), 819-833. https://doi.org/10.1057/palgrave.jibs.8490053

W.beard, D., \& Dess, G. G. ( 1981). Corporate-Level Strategy, Business-Level Strategy, and Firm Performance. The Academy of Management Journal, 24(4), 663-688. https://doi.org/10.2307/256169

Wurgler, M. B. (2002). Market Timing and Capital Structure. The Journal of Finance, 57(1), 1-32. https://doi.org/10.1111/1540-6261.00414

\section{Copyrights}

Copyright for this article is retained by the author(s), with first publication rights granted to the journal.

This is an open-access article distributed under the terms and conditions of the Creative Commons Attribution license (http://creativecommons.org/licenses/by/4.0/). 